UDC 316.35

\title{
VIRTUAL VOLUNTEERS: NEW STRATEGIES OF VOLUNTEERING DURING THE PANDEMIC OF COVID-19
}

\author{
(C) Narine L. Wiegel \\ Rostov State Medical University, Rostov-on-Don, Russian Federation \\ science-almanac@mail.ru
}

The article is devoted to the analysis of volunteer activity during the crisis of a social life, that is the pandemic of coronavirus infection. The situation of mass stress and fear during the period of isolation has launched mechanisms of mental instability, increased emotionality, as well as the breakdown of social connections, which affects the mental and physical health of a person extremely negatively. And only volunteers tried and try to compensate for the lost sociality through sociality, which is relevant in the crisis situation of human existence. As the virus continues to spread rapidly around the world, including in Russia, telemedicine is an important risk reduction strategy for healthcare professionals, patients and their families. The situation with the spread of coronavirus infection implies a reduction in physical contacts, which contributes to the emergence of a new volunteering strategy, that is a virtual volunteering, which can relieve psycho-emotional concern, as well as take on the mission of educating the population. Virtual volunteering can serve as an intermediary between the interpersonal physical contact of volunteers and those who need the help of volunteers. It should be noted that the creation of infrastructure for virtual volunteering during this pandemic may be applicable in the future. Both during and after the pandemic, virtual volunteering can protect immunocompromised patients and volunteers, isolated or otherwise at high risk, while still allowing them either to receive or to provide psychological and information and awareness-raising services.

Key words: volunteer, volunteering, social practice, social demand, expansion of social experience, self-knowledge and self-development.

\section{[Н.Л. Вигель Виртуальные волонтеры: новые стратегии волонтерства во время пандемии COVID-19]}

Статья посвящена анализу волонтерской деятельности во время кризиса социальной жизни пандемии коронавирусной инфекции. Ситуация массового стресса и страха в период изоляции запустила механизмы психической нестабильности, повышенной эмоциональности, а также разрыв социальных связей, что крайне негативно сказывается на психическом и физическом здоровье человека. И только добровольцы пытались и пытаются компенсировать утраченную социальность посредством социальности, актуальной в кризисной ситуации человеческого существования. Поскольку вирус продолжает стремительно распространяться по всему миру, в том числе и в России, телемедицина является важной стратегией снижения риска для медицинских работников, пациентов и их семей. Ситуация с распространением коронавирусной инфекции предполагает сокращение фризических контактов, что способствует возникновению новой стратегии волонтерства - виртуального волонтерства, которое способно разгрузить психоэмоциональную обеспокоенность, а также взять на себя миссию просветительской работы с населением. Виртуальное добровольчество может служить посредником между межличностным ффизическим контактом волонтеров и лиц, нуждающихся в помощи добровольцев. Следует отметить, что создание инфраструктуры для виртуального добровольчества во время этой пандемии может быть применимо и в будущем. Как во время, так и после пандемии виртуальное добровольчество может защитить пациентов и добровольцев с ослабленным иммунитетом, изолированных или иным образом подверженных высокому риску, продолжая при этом позволять им либо получать, либо предоставлять психологические и информационно-просветительские услуги.

Ключевые слова: волонтер, волонтерство, социальная практика, социальная востребованность, расширение социального опыта, самопознание и саморазвитие.

Narine L. Wiegel - Ph.D. (Advanced Doctorate) in Philosophy, Professor, Rostov State Medical University, Rostov-on-Don, Russian Federation.

Вигель Нарине Липаритовна - доктор философрских наук, профрессор, Ростовский государственный медицинский университет, г. Ростов-на-Дону, Российская Федерация. 
Before starting to consider the topic, we would like to remind that there is volunteering. The Federal Law of August 11, 1995 N 135-Federal Law "On Charitable Activities and Volunteering" defines the following: "Voluntary activities mean voluntary activities in the form of voluntary work and (or) the provision of services for the purposes specified in paragraph 1 of Article 2 of this Federal Law". In accordance with the Order of the Government of the Russian Federation dated December 27, 2018 No. 2950-r "Volunteering is an activity in the form of voluntary work and (or) the provision of services for solving social problems in such areas as education, health, culture, social support and social services of the population, physical culture and sports, environmental protection, prevention and elimination of the consequences of emergency situations" [1]. A volunteer translated from Latin "voluntarius" is a volunteer. Volunteering is voluntary activities chosen consciously and having no commercial benefit.

During the quarantine period, a special site \#MYVMESTE was created [2]. This is a mutual assistance campaign that is aimed at supporting elderly, people with limited mobility and medical staff during the coronavirus pandemic. On this site you can both get help and offer it. And there are also various ways to help people, from donations and donorship to the payment for the trip of medical workers.

In addition to ordinary people, various firms and companies are engaged in volunteering. For example, car companies such as BMW, Mercedes-Benz, Hyundai, KIA provided cars for volunteers to buy food and medicine, and then to deliver them to those in need; the French company Leroy Merlin provided the volunteer headquarters of the regions with all the necessary furniture; the commercial bank Tinkoff allocated 2 million rubles for the purchase of product sets, 500 SIM cards for volunteers, debit cards for operating costs and these are not all the examples.

According to the statistics of the website \#MYVMESTE, today (20.09.2020) there are 118,985 volunteers, 9,402 offers from partners, 3,450,646 people who received assistance, $3,161,965$ hotline calls. Assistance is provided in different ways, and even the smallest, at first glance, support can play a decisive role in a particular situation.

The reasons of volunteering are primarily altruistic (people want to help those in need selflessly), as well as social and career: participants want to expand the social circle, find like-minded people, and get professional skills. Psychologists, however, emphasize that the motives for participating in volunteer projects are heterogeneous and largely depend on the nature of the activity itself, the age of volunteers, the duration of their participation in projects, etc.

For young people, volunteering is most often a way to gain the experience and establish the links necessary for their future career, and older people consider voluntary assistance to be a basic life value.

Since 2019, the share of those who believe that most people can be trusted has increased slightly (from $23 \%$ to $26 \%$ ), while about $30 \%$ of respondents believe that over the past month the level of confidence among Russians has decreased; $75 \%$ of respondents trust people from their inner circle.

Irina Mersiyanova, associate professor of the Faculty of Social Sciences explains that the generalized trust refers to the basic values, and they do not change quickly, so the fundamental indicator (26\% of those who trust the majority) did not decrease, and the momentary (an assessment of the situation over the past month) turned to pessimism.

According to the survey, $58 \%$ of adult Russians are ready to unite with others for joint initiatives. Among supporters, $72 \%$ are determined to act together to support those in quarantine, $28 \%$ have already done this.

When asked whether you are happy or not, in general, $79 \%$ answered "yes", $30 \%$ answered "certainly" and 49\% answered "rather happy." Researchers are not surprised by the high proportion of happy people in difficult times: the level of happiness in our country is 
traditionally high. According to the All-Russian Public Opinion Research Center, despite the pandemic, $81 \%$ of Russians feel partially or completely happy.

Happiness is associated with attitudes towards other people, among those who trust the majority, 85\% consider themselves happy, among those who do not trust, $78 \%$ of people are happy, and the share of unhappy people in the second group is almost twice as high. The study is based on 2012 telephone interviews according to the all-Russian representative sample conducted from April 1 to May 3.

Despite the feeling of happiness, it is noted that during the pandemic of coronavirus infection, young people suffered the most, since they are most active in society in terms of productivity, mobility and interaction, so this crisis was devastating in terms of their lifestyle and future prospects. On the other hand, young people responded to the pandemic in terms of digital technologies and offered new solutions to socialization during isolation. Volunteers are willing to share their experience of using new technologies to expand exchanges between students both regionally and internationally.

Volunteers were able to "master" all sectors of our society, and medical services were able to evaluate and benefit from their incredible commitment to the cause. Volunteers, from various perspectives, perceived their work, actions and programs, and also indicated how they were changing the situation for the better due to their voluntary work in the region to assist older persons severely affected by the pandemic crisis.

The pandemic situation has highlighted positive aspects, as it has led to greater awareness, sympathy and solidarity, instilling positive initiatives among young people [3-5]. Despite the concern caused by the pandemic, the invaluable voluntary work in which young people are actively involved can be appreciated highly, and the fact how due to these challenges and their positivity volunteers have helped to restore normal social life also can be appreciated.

Even before the advent of COVID-19, health systems began to implement virtual options. It is already clear that telemedicine is a highly profitable solution to improve healthcare efficiency and patient satisfaction while reducing waiting times and increasing accessibility. However, telemedicine can provide disproportionate benefits to the members of higher socioeconomic classes, as they are more likely to have reliable Internet connections and devices. Given the complex economic and health aspects, lack of access to technology can prevent the benefits of telemedicine from being available to the population most severely affected by COVID-19. Telemedicine does increase the ability of most people to consult a doctor. The pandemic of COVID-19 accelerated the introduction of telemedicine. As the virus continues to spread rapidly around the world, including in Russia, telemedicine is an important risk reduction strategy for health services, patients and their families.

The spread of COVID-19 through asymptomatic carriers has been studied well and supports the introduction of telemedicine and limiting hospital staffing to essential staff. It should be taken into account that hospitals are not the only health systems that use telemedicine, since many primary care practices also use virtual meetings. Virtual meetings have become commonplace in non-medical fields, especially in education and business. Across the country, students of universities have started to study online, and enterprises have canceled intra-company operations and started to work remotely. Nevertheless, the work on the introduction of virtual volunteering programs in hospitals is not practiced. Medical volunteers clearly perform important psychological and educational services that benefit patients, and as in other areas, volunteer programs should strive to develop virtual alternatives.

It is important to note that many of the strengths of telemedicine are directly related to virtual volunteering. Virtual volunteering would be an important risk reduction strategy in providing patients with vital support during this pandemic. Virtual volunteering reduces the risk of infection with the virus, minimizing personal contact and adhering to strict guidelines 
established by hospitals for essential staff. Importantly, the combination of asymptomatic carriers and failure to introduce widespread testing makes recovery of hospital volunteering unlikely in the nearest future. Developing virtual programs for some services that volunteers regularly provide is an important way to protect volunteers, community members, patients, and doctors, who are at high risk of COVID-19. In general, this could be an effective way to improve the safety of our "heroic front-line workers" and ensure the protection of the whole society.

The need for telemedicine encourages hospitals to enter into contracts with video conferencing software companies. In addition, the social distance guide adopts experienced users of various video conferencing platforms. There are also extensive resources available to train beginners to use these platforms. Volunteers could use video platforms such as Zoom, which have already entered into contracts with many healthcare systems. These platforms are also widely used by the public, making them attractive for virtual volunteering. Despite the obvious need for virtual volunteering programs, they have limitations that need to be addressed. There must be a way to control how volunteers interact with patients. However, such problems are largely offset by potential benefits and can be addressed through mandatory virtual trainings before the patient contact is resolved.

Virtual volunteering in hospitals cannot replace the tasks that volunteers typically perform in hospitals, but it can solve important problems associated with contacts with patients that volunteers had provided before the pandemic. Volunteering in a virtual hospital can allow patients to start receiving the vital educational support they previously had before COVID-19 again. It is important to note that virtual volunteering minimizes the risk to all involved to prevent the virus from spreading further. In addition, virtual programs can be expanded beyond hospital patients to help to provide palliative care or help hospice patients with critical end-of-life support, or even provide educational support to families of those who risk their lives on the frontline daily. As the principles of social distancing remain valid, virtual volunteering offers emotional support and comfort to patients who do not have friends or family to contact, or who are unable to contact their loved ones due to the lack of access to technology.

While virtual volunteering can mediate personal physical volunteering during a pandemic, it is not an absolute substitute. However, the creation of infrastructure for virtual volunteering during this pandemic may be applicable in the future. Both during and after the pandemic, virtual volunteering can protect immunocompromised patients and volunteers, isolated or otherwise at high risk, while still allowing them either to receive or to provide emotional and educational services.

To sum up, volunteering in this difficult period allowed people to pull together and become stronger, more confident in themselves. It is difficult to imagine how the world would do without volunteers, especially during the pandemic, when assistance is required several times more than in normal times. Therefore, volunteering is an essential resource that requires reorganization in connection with the new challenges of global problems.

"Helping others is the need of the soul, unless you are selfish or you have no soul. Helping others gratuitously is the quality of a kind soul that knows how to sympathize and empathize. Our special duty is that if anyone is particularly in need of our help, we are to make every effort to help that person."

Marcus Tullius Cicero

\section{Лumepamypa}

1. Распоряжением Правительства Российской Федерации от 27 декабря 2018 г. №2950-р «Об утверждении Концепции развития добровольчества (волонтерства) в РФ до 2025 г.» 
URL: http://static.government.ru/media/files/e6LFLgABRP4MyQ8mW7HCICGR8esYB Ygq.pdf

2. Сайт волонтерского движения \#MЫBMECTE: [Электронный ресурc] URL: https://мывместе2020.pq/

3. Алоян Н.Л., Черникова В.Е. Человек в современном культурном пространстве. Ростов-на-Дону: издат-во Антей, 2009.

4. Вигель Н.Л. Человек в культуре постмодерна // Экономические и гуманитарные исследования регионов. 2015. № 2. С. 114-117.

5. Алоян Н.Л. Категория трагедии. // Гуманитарные и социально-экономические науки. 2008. № 2. С. 80-82.

\section{References}

1. Rasporiazheniem Pravitelstva Rossiiskoi Federatsii ot 27 dekabria $2018 \mathrm{~g}$. №2950-r "Ob utverzhdenii Kontseptsii razvitiia dobrovolchestva (volonterstva) v RF do 2025 g" [By Order of the Government of the Russian Federation dated December 27, 2018 No. 2950-r "On Approval of the Concept for the Development of Volunteering in the Russian Federation until 2025".] Available at: http://static.government.ru/media/files/e6LFLgABRP4MyQ8mW7HCICGR8esYBYgq.p df

2. Sait volonterskogo dvizheniia \#MYVMESTE [Site of the volunteer movement \#MYVMESTE]: Available at: https://мывместе2020.pq/

3. Aloyan N.L., Chernikova V.E. Chelovek v sovremennom kulturnom prostranstve. Rostov-na-Donu: izdatelstvo Antei. [A man in the modern cultural space. Rostov-on-Don: Antey Publishing House], 2009 (in Russian).

4. Wiegel N.L. Chelovek v kulture postmoderna. Ekonomicheskie i gumanitarnye issledovaniia regionov [A man in the culture of postmodern. Economic and humanitarian research of regions]. 2015. No. 2. pp. 114-117 (in Russian).

5. Aloyan N.L. Kategoriia tragedii. Gumanitarnye i sotsialno-ekonomicheskie nauki [Category of tragedy. Humanitarian and socio-economic sciences]. 2008. No. 2. pp. 80-82 (in Russian). 